\title{
Implementation of Total Quality Management at UPT Nganjuk Children's Social Services, Indonesia
}

\author{
Ariadi Santoso* \\ Faculty of Economic \\ Kadiri University, Indonesia. \\ ariadi_santoso@unik-kediri.ac.id
}

\author{
Kartika Yuliari \\ Faculty of Economic \\ Kadiri University, Indonesia. \\ kartikay@unik-kediri.ac.id \\ Priyo Prasetyo \\ Faculty of Economic \\ Kadiri University, Indonesia. \\ priyoprasetyo@unik-kediri.ac
}

\author{
Sudjiono \\ Faculty of Economic \\ Kadiri University, Indonesia \\ sudjiono@unik-kediri.ac.id
}

\begin{abstract}
Orphanages at UPT Nganjuk Children's Social Services are established with the aim of nurturing, guiding, directing, giving love, and meeting the needs of underprivileged children. The study entitled " Implementation of Total Quality Management at UPT Nganjuk Children's Social Services, Indonesia" is a study that focuses on how the implementation of total quality management at UPT Nganjuk Childcare Social Services. This type of research is a qualitative study, while the specifications of this study are descriptive. The data collection methods used are interviews, observation, and documentation. The results of the study can be concluded as follows: (1) The management system at UPT Nganjuk Child Care Social Services when viewed from the elements of Total Quality Management (TQM) which includes: (a) customer focus, (b) improvement of quality, (c) ) cooperation in teamwork, it can be said that the Orphanage has implemented quality management. (2) Improving the quality of orphanage services is done by preparing a strategic plan that is realized in the development plan that contains the vision, mission, and objectives as well as the strategic program of the Orphanage as well as a clear division of tasks. Students are well served, starting from the learning process inside and outside the care beach. Thus the quality of service at UPT Nganjuk Child Care Social Services is satisfactory.
\end{abstract}

Keywords: Implementation, Orphanage, Total Quality Management.

\section{INTRODUCTION}

There are no definitive data about children whose lives have been abandoned. It's just that from the eye's eye, it can be seen that there are children who make the streets their place of life. It is undeniable that there are still many children who are not of the same age and still have a low level of education. This is because family income is still minimal, so there is no cost for children's education. The next consequence of not obtaining welfare and education in children is a new, more severe problem. Street children, homeless people, and children who work as beggars are examples of this problem. Some of the causes of this are parents who die or do not have relatives to care for them, parents are unable (very poor), so they cannot meet the minimum needs of their children.
The results of sustainable development must be able to reach and touch the problems of children. Ensuring children can grow freely in a conducive environment, which can give hope for a better future. Children who will inherit the leadership of this nation can give hope to be able to accept the leadership relay and maintain the existence of the Indonesian nation to remain victorious throughout all time. UNICEF data for 2019 shows that as many as 2.5 million Indonesian children cannot enjoy further education, namely 600 thousand elementary school-age children and 1.9 million junior high school-age children [1]. Likewise, statistical data released by BPS shows that at the provincial and district level, there are certain groups of children who are most vulnerable affected, most of whom come from lowincome families and are unable to continue their education to the next level [2].

National Education aims to develop the intellectual life of the nation and to develop fully Indonesian people. The state gets the mandate to carry out the best education for its people by considering various things, which include the ability of the education budget to provide infrastructure and supporting resources as well as adequate human resources to realize the mandate of the Law as well as possible through various methods and methods. To achieve this, we need a set of regulations or educational institutions that must lead to each educator. This is the future of the Indonesian people as expected. In the implementation of formal education organized by the Government, it is known that there is a tiered education from basic education to Higher Education[3]. It's just because there are groups of people who are still in the underprivileged group, which in this group has not been able to budget for family education, the Government, through the social department, provides orphanages and displaced orphanages (through Law ). Orphanage and neglected childcare institutions are used to accommodate children who have families with economic and social limitations.

Whereas improvement in the quality of human resources is a reality that must be planned, directed, intensive, effective, and efficient in the development process, otherwise a nation is unable to compete in undergoing the current era of globalization. Talking about the quality of 
human resources, education plays a significant role. Recognizing the importance of the process of improving the quality of human resources, the Government together with the private sector have both been and continue to strive to realize the mandate through various efforts to develop higher quality education, among others through the development and improvement of curriculum and evaluation systems, improvement of educational facilities, development and procurement teaching materials, as well as training for educators, and their workforce [4].

The orphanage institution that accommodates orphans and abandoned children managed by the Ministry of Social Affairs is a solution to overcome the problems of orphans and abandoned children [5].

This institution functions to accommodate orphans and neglected children to be cared for, educate formally, or informally with a communal family upbringing pattern. This institution does not provide a complete solution to the solution, but only as an intermediary to deliver orphans and abandoned foster children, gain provision of experience as family care and obtain formal or informal education as expected to become stock when they are freed and become themselves economically independent and social.

Laws and regulations are governing the management of childcare institutions from this social service. But specifically, each childcare institution has different characteristics that are influenced by the socio-cultural values of the surrounding community. The management of orphaned and neglected foster care institutions needs good managerial arrangements, with a certain scope of activities to support the success of this childcare institution successfully delivering their foster children by its founding goals. If the education component, namely caregivers, foster children, material, media is processed with good managerial management, educator activities will take place smoothly in accordance with the desired goals. Because after all, an activity that really requires proper management if you want to be able to walk perfectly [6]. In this case, the educator must, of course, have to know exactly explore the needs of children who have not been guaranteed the prosperity of life and education.

The Orphanage is essentially a social institution that has a service program that is provided to answer the needs of the community in order to deal with social problems, especially the problems of poverty, ignorance, and problems of orphans, abandoned children who develop in the community [7].

The purpose of the establishment of orphanages is to help and, at the same time, as a substitute parent for abandoned children and whose parents have died to provide a sense of security physically and spiritually, give love, and provide compensation for their lives [8]. The aim is to deliver them to be human beings who can help themselves, not depend on others, and benefit the community. One of them is the Nganjuk Children's Orphanage Technical Implementation Unit, abbreviated as UPT PSAA Nganjuk. This Orphanage sponsors and manages orphans, orphans, orphans, and underprivileged children.

The UPT Nganjuk Children's Social Service is an orphanage located on J1. The East Java Provincial Social Service founded veteran No.47 Nganjuk 64419. The UPT
Nganjuk Child Care Social Services is a social institution that has been active since 1956 in Nganjuk Regency. In this Orphanage, there are 60 children who live in the boarding house, and there are 47 caregivers/teachers who will accompany them to become more independent people and have a good future.

Thus, the orphanage institution must try to take steps in the form of educational innovations in a professional manner with reliable management, so that the educational institution can produce reliable outputs in society, good, ready in their intellectual, skill, and spiritual [9].

Therefore, from the above understanding explains that the Orphanage is one system to improve the quality of human life in all aspects of human life, both morally, spiritually as well as materially and intellectually [10]. In the current era of globalization to realize the hopes and goals of the Orphanage is not easy. Of course all of that is a shared responsibility between the Government in general and education experts in particular. Because education in the present era is faced with the challenges of modern human life, education must be directed at the changing needs of modern society. To react to this, a new paradigm of education is needed in the face of new demands.

So with its diversity, the Orphanage must be able to take care of themselves in accordance with environmental conditions and the needs of their students so that the resulting output is really in accordance with what is expected by consumers, namely foster children and society in general. With this approach, the spearhead of efforts to improve the quality of orphanages lies with the Orphanage itself. When the Government gives an opportunity to the orphanage authorities to optimize their full potential, various methods are implemented, one of them is by implementing Total Quality Management in the Orphanage to achieve the quality of education they aspire to.

Fandi Tjiptono explained that Total Quality management is an approach in running a business that tries to maximize the organization's competitiveness through continuous improvement of its service products, workforce, processes, and environment

The existence of Total Quality Management (TQM) which is used in the application in the business world reaps very significant results, so that TQM has its own appeal, to be applied to other institutional or organizational objects, both in the political, social, including in the world education [11]. This is in the context of effectiveness and good results as desired targets.

Total Quality Management is a management approach in an institution, focused on quality and is based on the participation of all human resources and is aimed at longterm success through customer satisfaction and providing benefits to members of the human resource institution and society [12]. TQM is also translated as a customer-oriented approach that introduces systematic management changes and continuous improvement of an institution's processes, products, and services. The TQM process has an input that is specific to the wants, needs, and expectations of the customer, processing inputs within the institution to produce goods or services, which in turn gives satisfaction to the customer. The main objective of Total Quality Management is continuous improvement in service quality. Thus Quality 
Management itself must be carried out continuously. TQM is an effort to create a quality culture, which encourages all staff in an institution to satisfy customers. The TQM concept seeks to adapt to changing customer expectations and styles by designing products or services that meet and satisfy their expectations [13]

So it can be concluded that the rationale for the need for TQM is very simple, namely the best way to compete and excel in a competition by producing the best quality. To produce the best quality, continuous improvement is needed for human capability, processes, and the environment. In this case, TQM seeks to create an organizational system that can anticipate changes in the external environment that affect the expectations and needs of customers.

Likewise, the application of TQM in an orphanage, then in its management to improve quality and quality, must be carried out in an integrated and continuous manner so that the Orphanage as a service can meet the needs of customers both now and in the future. With the TQM approach, it is expected that the Orphanage will be able to produce quality output and can improve quality on an ongoing basis [14]. TQM considers that educational products as a service industry in the form of services, are provided to customers in accordance with certain quality standards. These services can be said to be satisfactory if they are in accordance with the wishes or exceed the needs of the customers concerned. To get quality school quality, what needs to be considered is not only in terms of infrastructure, but also the human resources in the Orphanage, namely the head of the Orphanage, caregivers and employees. Students / foster children act as consumers of orphanage services. As consumers, the satisfaction of students / foster children is an important indicator of the success of TQM implemented by orphanages. In addition to foster children there are also indirect consumers of orphanage services, namely children's parents. Parents' satisfaction is also a very important indicator in assessing the successful implementation of TQM in an orphanage. In this case the satisfaction of foster children and parents will be met if the results of implementing TQM are truly able to improve the quality of the Orphanage.

In the process towards an integrated quality orphanage, the head of the Orphanage, caregivers, staff/employees, and foster children must have an obsession and commitment to quality, namely quality education. Have a vision and mission of quality that is focused on meeting the needs and expectations of its customers, both internal customers, such as teachers and staff, as well as external customers such as foster children, foster parents, the community, Government, further education and the business world [14].

The application of TQM in the Orphanage can not be separated how the efforts of the head of the Orphanage can control the quality of the management of the Orphanage in an integrated manner [15]. Integrated quality control is the most effective system for integrating efforts in quality development, quality maintenance, and quality improvement from various levels of the organization to increase productivity. From this statement, it is implied that the Head of the Orphanage should be able to carry out quality control in an integrated manner to increase better and more effective results. The main basis to run it is a mentality, skills, and participatory management with a mental attitude that prioritizes quality work. The mentality is the willingness to work seriously, honestly, and responsible for carrying out his work.

Based on the above, it appears that the quality of the Orphanage is the accumulation of all the quality of services available at the Orphanage received by its customers. Orphanage service is a long process, and one activity is influenced by other activities. If all activities are carried out well, the final result of the Orphanage's services will achieve good results[14].

The UPT Nganjuk Child Care Social Services under the auspices of the East Java Government is one of the orphanage institutions which, according to observations, while the writer has also indirectly tried to implement some of the elements of TQM, which include customer focus, have an obsession with quality and teamwork, as well as applying TQM principles, namely: customer satisfaction, respect for everyone, fact-based management and continuous improvement[16].

Previous research by Subaidi (2018), about the study of orphanage institutions in handling orphans and abandoned children, among others, is evaluating the application or implementation of regulations contained in orphanages in the management of foster children. The results of the study indicate a deviation because the graduate output cannot always be independent. Some note of the cause is the existence of unequal expectations about graduate output.

In the field of industrial research, Total Quality Management has been carried out by Baros (2014), taking the title "Quality Management Principles and Practices Impact on the Companies' Quality Performance". The results show that TQM practices have a positive and significant effect both on organizational performance and competitive advantage. Competitive advantage has a positive and significant effect on organizational performance. Organizational performance is more influenced by competitive advantage than TQM practices [17]. Snezana Topalovic (2014), conducted a study entitled "The implementation of Total Quality Management in order to improve production performance and enhance the level of customer satisfaction. The results of the research point out that top management's commitment, courtesy and responsibility towards our customers as significant factors of satisfaction. Study results help bank managers to identify quality elements that need to be improved, to increase the level of customer satisfaction and enhance their business [18].

Departing from the facts that have been presented before, the researcher is interested in examining this problem with the title: "Implementation of Total Quality Management in UPT Nganjuk Children's Social Services, Indonesia".

Based on the background above, a problem statement can be taken, namely: How is the implementation of Total Quality Management in the UPT Nganjuk Children's Social Services?

\section{Research Objectives and Benefits}

a. To find out the implementation of Total Quality Management at UPT Nganjuk Children's Social Services. 
b. To find out the orphanage services at UPT Nganjuk Children's Social Services.

The results of this study could be taken into consideration for the Nganjuk Children's Social Services UPT in optimizing the management of the Orphanage. The results of this study are expected to provide knowledge and add to the scientific treasures in the management of the Orphanage.

\section{METHOD}

This research is a type of qualitative research. Qualitative research is research that intends to understand the phenomena about what is experienced by research subjects. In this study, the method is used to obtain accurate and complete data based on the facts that are complete about the UPT Nganjuk Child Care Social Services.

Subjects and Informants, in this study, the research subjects as the most responsible source were: Head of UPT Nganjuk Child Care Social Services. As for the informants in this study are caregivers, foster children, educational staff, and the community (student guardians).

The data collection techniques in this study are using observation, interviews, and documentation. The data analysis technique used in this research is to use descriptive data analysis techniques.

Checking the validity of the data in this case, the author follows Moleong's opinion in measuring how far the truth of the research results can be trusted or the degree of trustworthiness or credibility. To achieve credibility, techniques will be used (a) triangulation of data sources, namely comparing and checking information obtained by comparing observational data with interviews, comparing what people say in public with what is said privately, comparing the results of interviews with content a related document. The expected result of the comparison is in the form of similarities or reasons for differences.

\section{RESULT AND DISCUSSION}

\section{A. Profile UPT Nganjuk Child Care Social Services.}

The UPT Nganjuk Children's Social Service is an orphanage located on J1. The East Java Provincial Social Service founded veteran No.47 Nganjuk 64419. The UPT Nganjuk Child Care Social Services is a social institution that has been active since 1956 in Nganjuk Regency. In this Orphanage, there are 60 children who live in the boarding house, and there are 47 caregivers/teachers who will accompany them to become more independent people and have a good future.

The UPT Nganjuk Child Care Social Services has a Vision and Mission:

The vision of the UPT Nganjuk Childcare Social Service is "The realization of a professional Childcare Services institution based on social work standards through joint efforts of the Government and the community." To achieve this vision. Mission has been formulated as follows:

1. Encourage and support the expansion of the increase in the implementation of social welfare development for neglected children by the Government and society;
2. Developing the potential and sources of social welfare as well as increasing the professionalization of social welfare development implementers;

3. Organizing child care services that are holistic, comprehensive and by social work service standards;

4. Building a network and collaboration with related parties.

Organizational Structure of UPT Nganjuk Children's Social Services: Children's Social Services:

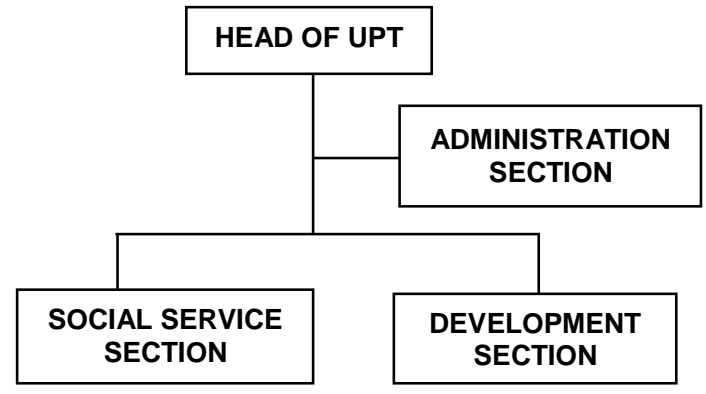

Figure 1 . Organization Composition Chart At Upt Nganjuk Children's Social Care Service

\section{B. Implementation of Total Quality Management at UPT NganjukChildren's Social Services}

TQM is a management system that is oriented to the improvement and improvement of service quality from the provider of goods or services to the users (consumers). The main objective of TQM is to improve total quality.

Implementation of TQM in the UPT Nganjuk Child Care Social Services by some of the elements of TQM, namely 1). Customer focus, 2). Obsession with quality, 3) Teamwork, as explained below:

\section{1) Customer Focus}

Customers are all people who demand us to meet certain quality standards as they wish. Judging by the type of customer, the school is said to be successful if

a. Foster children are satisfied with the products of the Orphanage, among others are satisfied with the teaching received, satisfied with the treatment by caregivers and leaders, satisfied with the facilities provided by the Orphanage. That is, participants enjoyed the orphanage situation. The implementation of TQM at the UPT Nganjuk Childcare Social Service can be proven from several expressions of foster children there who convey their satisfaction with the services provided at the UPT Nganjuk Childcare Social Services, namely by having fun learning, there are several extra programs and activities available, moreover, the discipline of caregivers and the good example of caregivers, is what makes students enthusiastic in learning.

b. Parents of foster children are satisfied with the product for their children or products to parents, for example satisfied because they received periodic reports about the development of students and orphanage programs. And as a forum for proposals from student guardians, the UPT Nganjuk Child Care Social Services has formed a 
student guardian community, which is held regularly every month. As explained by Ms. Mutmainah, one of the guardians of students there, who expressed her satisfaction because her child won first place at MTQ at the district level and could represent at the provincial level in East Java.

\section{2) Obsession With Quality}

In organizations that implement TQM, the final determinant of quality is internal and external customers. Customers assume that the product is more quality than its competitors. With the quality specified, the organization must be obsessed with starting or exceeding what is determined. This means that all employees at every level try to carry out every aspect of their work based on the perspective of how we can do it better. Both foster children and caregivers both have the same desire to improve the quality of the Orphanage better. By jointly improving the existing quality, the Orphanage will also meet and exceed the existing quality. The output from the UPT Nganjuk Childcare Social Services can be more independent and have a good future. This was expressed by Mr. Sumarno as the community.

Likewise, caregivers and employees are satisfied with orphanage products, for example the division of labor, relationships between caregivers, employees and leaders. As revealed by the head of the Nganjuk Childcare Social Services UPT that at the beginning of each year a division of labor has been held for caregivers and employees of the UPT Nganjuk Childcare Social Services, so that each of them works according to their duties. Alternately caregivers are sent to attend the Training in order to improve the quality of their work.

\section{3) Teamwork}

In organizations that implement TQM, teamwork, partnerships and relationships are established and fostered, both among employees, government agencies, and surrounding communities. The environment of the Orphanage has multi elements which in order to get good quality it requires cooperation from the related elements. The elements of the Orphanage referred to are the head of UPT, caregivers, foster children, administrative staff, guardians of students / surrounding communities and the government. If they support one another, the Orphanage can improve its quality.

As for the UPT Nganjuk Childcare Social Services as an expression of some caregivers and UPT heads, that there is a good collaboration in order to advance the Orphanage, attention from a good government, which is always monitoring the development of the Orphanage and meeting the needs of the Orphanage in terms of facilities and infrastructure, caregivers and employees work well and passionately, and the head of UPT has a good leadership spirit.

Obstacles to Implementation of the TQM in the UPT Nganjuk Child Care social Services. The obstacles that are still found in the implementation of TQM in the UPT Nganjuk Child Care Social Services include: a). Lack of discipline of some caregivers in carrying out their duties and obligations, and $b$ ). The TQM that is implemented cannot yet be accepted by all parties with full awareness in providing the best and maximum service to customers in order to improve quality at the Orphanage.

\section{CONCLUSION}

The results of the study can be concluded as follows: (1) The management system at the UPT Nganjuk Child Care Social Services when viewed from the elements of Total Quality Management (TQM) which includes: (a) customer focus, (b) improvement of quality, (c) ) cooperation in team work, it can be said that the Orphanage has implemented quality management. (2) Improving the quality of orphanage services is done by preparing a strategic plan that is realized in the development plan that contains the vision, mission, and objectives as well as the strategic program of the Orphanage as well as a clear division of tasks. Students are well served starting from the learning process inside and outside the care beach for example by habituating Duha prayer, pilgrimage to Dhuhr prayer and extracurricular activities. Thus the quality of service at UPT Nganjuk Child Care Social Services is satisfactory.

\section{ACKNOWLEDGMENT}

The researcher wants to acknowledge Kadiri University, especially the Economi Faculty, for giving a chance for doing the research and composing the report.

\section{REFERENCES}

[[1] I. R. H. Abdul, M. Muhammad, and A. Bandar, "IMPLEMENTATION OF ORGANIZATIONAL MANAGEMENT AT THE ORPHANAGE IR.H. ABDUL MALIK MUHAMMAD ALIUN BANDAR LAMPUNG," Fac. DA'WAH Commun. Sci. Univ. Islam NEGERI RADEN INTAN LAMPUNG, no. Md, p. 102, 2017.

[2] H. Sarujin, "IMPLEMENTATION OF ISLAMIC EDUCATION MANAGEMENT IN THE CONSTRUCTION OF NOBLE MORALITY FOR ORPHANAGE CHILDREN IN MAKASSAR CITY," J. Islam. Discursus, vol. 2, pp. 275-288, 2014.

[3] N. D. Al-qahtani, S. Sa, and A. A. Aziz, "Impact Of Quality Management On Organizational Performance," Int. J. Sci. Technol. Res., vol. 3, no. 8, pp. 271-282, 2014.

[4] L. Priyanka and M. Setiawan, "THE EFFECT OF TOTAL QUALITY MANAGEMENT ON THE PERFORMANCE OF SMES THROUGH MEDIATION VARIABLE OF ORGANIZATIONAL COMMITMENT," J. Apl. Manaj., vol. 15, no. 1, pp. 116-125, 2017, doi: 10.18202/jam23026332.15.1.14.

[5] K. Kodarni, "SOCIAL SERVICES MANAGEMENT AT HASANA PEKANBARU ORPHANAGE," J. Dawah Risal., vol. 28, no. 2, p. 82, 2017, doi: 10.24014/jdr.v28i2.5546.

[6] R. A. Al-Damen, "The impact of Total Quality Management on organizational performance Case of Jordan Oil Petroleum Company," Int. J. Bus. Soc. Sci., vol. 8, no. 1, pp. 192-202, 2017. 
[7] U. Rahmah, "The Implementasi Total Quality Management (TQM) di SD Al-Hikmah Surabaya," Manag. J. Manaj. Pendidik. Islam, vol. 3, no. 1, pp. 111131, 2018, doi: 10.14421/manageria.2018.31-06.

[8] M. Tribus, "Total Quality Management in education," Dev. Qual. Syst. Educ., vol. 4750, p. 83, doi: 10.4324/9780203423660_chapter_5.

[9] E. Meisaroh, "IMPLEMENTASI TOTAL QUALITY MANAGEMENT (TQM) DI MI MUHAMMADIYAH GADING I KLATEN," Inst. Agama Islam Negeri Surakarta, 2015.

[10] S. S. Khalim, “THE IMPLEMENTATION OF TOTAL QUALITY MANAGEMENT (TQM) AS EFFORT TO INCREASE THE SCHOOL EDUCATION QUALITY (Case Study in Islamic Vocational School Datuk Singaraja Kerso Kedung Jepara)," J. SMaRT Stud. Masyarakat, Reli. dan Tradisi, vol. 04, no. 02, pp. 221-230, 2018.

[11] K. E. Loum Janani, Kanwezi Henry, "Implementation of Total Quality Management and Interpersonal Communication in Achieving Student Satisfaction through Service Quality at Yayasan Pendidikan Islam, Miftahussalam, Medan,” Int. J. Res. Rev., vol. 2, no. 6, pp. 343-347, 2015.

[12] F. Fatimah and S. Solikin, "The Effects of Total Quality Management Implementation on Employees' Performance: The Case of PT Pertamina Refinery Unit III Plaju, Palembang-Indonesia,” Bus. Manag. Strateg., vol. 7, no. 1, p. 96, 2016, doi: 10.5296/bms.v7i1.9080.

[13] A. N. Ubay, M. Marimin, and Y. Arkeman, "Designing Strategies for Improving Total Quality Management in Manufacturing Industries,” Indones. J. Bus. Entrep., vol. 3, no. 32, pp. 131-142, 2017, doi: 10.17358/ijbe.3.2.131.

[14] H. S. Al-Dhaafri, R. Z. Bin Yusoff, and A. K. Al-Swidi, "The Effect of Total Quality Management, Enterprise Resource Planning and the Entrepreneurial Orientation on the Organizational Performance: The Mediating Role of the Organizational Excellence --- A Proposed Research Framework," Int. J. Bus. Adm., vol. 4, no. 1, pp. 66-85, 2013, doi: 10.5430/ijba.v4n1p66.

[15] A. Addae-Korankye, "International Journal of Asian Social Science TOTAL QUALITY MANAGEMENT ( TQM ): A SOURCE OF COMPETITIVE ADVANTAGE . A COMPARATIVE STUDY OF MANUFACTURING AND SERVICE FIRMS IN GHANA,” Int. J. Asian Soc. Sci., vol. 3, no. 6, pp. 1293-1305, 2013.

[16] S. K. Yeng, M. S. Jusoh, and N. A. Ishak, "The impact of Total Quality Management (TQM) On competitive advantage: A conceptual mixed method study in the Malaysia Luxury hotel industries," Acad. Strateg. Manag. J., vol. 17, no. 2, pp. 1-9, 2018.

[17] S. Barros, P. Sampaio, and P. Saraiva, "Quality Management Principles and Practices Impact on the Companies ' Quality Performance,” Int. Conf. Qual. Eng. Manag. Japan, vol. V1-5, pp. 237-247, 2014.

[18] S. Topalović, "The Implementation of Total Quality Management in Order to Improve Production Performance and Enhancing the Level of Customer Satisfaction," Procedia Technol., vol. 19, pp. 1016-1022, 2015, doi: 10.1016/j.protcy.2015.02.145. 